\title{
Conjunctivitis as a Sentinel of SARS-CoV-2 Infection: a Need of Revision for Mild Symptoms
}

\author{
Alexios A. Panoutsopoulos ${ }^{1,2}$ (C) \\ Accepted: 11 June 2020 / Published online: 19 June 2020 \\ (C) Springer Nature Switzerland AG 2020
}

\begin{abstract}
COVID-19 has been declared a pandemic by the World Health Organization on March 11, and since then, more than 3 million cases and a quarter million deaths have occurred due to it. Lately, there is a growing evidence for an ophthalmologic symptom (conjunctivitis) to be connected with the disease. This seems to happen in early stages of the infection by SARS-CoV-2, and thus, it is of major importance to understand the mechanism through which the virus can facilitate such a symptom. Here, we are proposing a molecular mechanism through which the novel coronavirus could act in order to affect the eye and use it as another, secondary but alternative, point of entry to the host organism.
\end{abstract}

Keywords COVID-19 · SARS-CoV-2 · Pandemic · Conjunctivitis · Pink eye · Ophthalmology $\cdot$ ECM proteins · ACE2 · HSPG · Picornavirus $\cdot$ Molecular ophthalmology

\section{Introduction}

The SARS-CoV-2 virus, a novel coronavirus, emerged in December 2019 in China, and then Japan, South Korea, Europe, and North America. On March 11, 2020, the World Health Organization declared the spreading novel coronavirus outbreak as a pandemic, thus showing the possibility that the virus spread to all countries worldwide [1]. As of May 13, 2020, about 4.5 million confirmed cases of coronavirus disease 2019 (COVID-19) and almost 300,000 deaths have been reported, with one third of the cases and more than $25 \%$ of the deaths to have occurred in the USA (John Hopkins Coronavirus Resource Center statistics). In response to the most serious global health threat in a century, researchers from all biomedical fields worldwide have participated in an unprecedented response to the

This article is part of the Topical Collection on Covid-19

Alexios A. Panoutsopoulos

apanoutsopoulos@ucdavis.edu

1 Department of Pathology and Laboratory Medicine, University of California, Davis, CA, USA

2 Institute for Pediatric Regenerative Medicine, Shriners Hospitals for Children, Northern California, 2425 Stockton Boulevard, Sacramento, CA 95817, USA
COVID-19 pandemic, with rapidly increasing resources aimed at finding safe and effective treatments for the disease (comprehensively reviewed in [2]).

Research for treatments has emerged from different backgrounds, pharmacologically with the use of well-known drugs for other diseases [3-7], with corticosteroids [8], immunologically from the serum of antibodies against former coronaviruses or from patients that have recovered from COVID-19 [9-11] or even with the use of revolutionary ideas such as CRIPR-Cas13 [12-14]. Another tremendous effort from NIH (ClinicalTrials.gov Identifier: NCT04283461) and all countries around the globe focuses on the successful development of a vaccine that would prevent the emergence of COVID-19 through the years and create a repeating cycle of spreading, like the influenza virus $[15,16]$.

While up to mid-April 2020, the only symptoms that were officially recognized as linked with COVID-19 were fever, cough, shortness of breath, or difficulty breathing, the CDC (Centers for Disease Control and Prevention) have lately updated the symptom list based on changes in the disease's definition adopted by the Council of State and Territorial Epidemiologists (CSTE). Chills, rigors, myalgia, headache, sore throat, and new olfactory and taste disorder(s) have been officially added in CDC's website as symptoms connected with SARS-CoV-2 infection. Moreover, gastrointestinal symptoms like nausea, vomiting, and diarrhea are stated as 
reported symptoms for the same disease in CDC's official website (CDC.gov). Importantly, it is already known that a substantial percentage of patients do not exhibit any symptom while infected with SARS-CoV-2 [17, 18].

In this review, we will focus on another symptom that has not been officially recognized, yet is arguably found in a small percentage of COVID-19 patients [19], and is of a major concern for ophthalmologists, i.e., conjunctivitis or pink eye. We will summarize all the cases reported in other publications, and through basic molecular biology mechanisms, we will propose a possible explanation of the etiology of this symptom.

\section{Background}

\section{The Molecular Biology of Coronaviruses and SARS- CoV-2}

Coronaviruses (CoVs) are RNA viruses with the largest RNA in base length identified so far and belong to the Coronaviridae family. They are divided into 4 groups: $\alpha-$, $\beta-, \gamma-$, and $\delta-\mathrm{CoV}[20]$. SARS-CoV and SARS-CoV-2 have $89.8 \%$ sequence identity in their spike (S) protein $\mathrm{S} 2$ subunits, which mediate the membrane fusion process, and both of their S1 subunits utilize human angiotensin-converting enzyme 2 (hACE2) as the receptor to infect human cells [21]. Most importantly, the ACE2-binding affinity of the $\mathrm{S}$ protein of SARS-CoV-2 is 10- to 20-fold higher than that of SARS$\mathrm{CoV}$ [15], which contributes to the higher infectivity of SARS-CoV-2 as compared with SARS-CoV [22].

After binding of the $\mathrm{S}$ protein of the virion to the ACE2 receptor on the target cell, the heptad repeat 1 (HR1) and 2 (HR2) domains in its S2 subunit of the S protein interact with each other to form a six-helix bundle (6-HB) fusion core [23], bringing viral and cellular membranes into close proximity for fusion and infection [24]. Therefore, the specificity of the virus is determined through the S-protein-receptor interaction to a host cell receptor. Cathepsin protease action is the first step for the virus in order to access the host cell's cytosol by proteolytic cleavage of the S protein, followed by fusion of the virus and the host's membranes. Fusion occurs within the endosomes and the formation of the bundle after fusion mixes viral and cellular membranes. As a result, the viral genome is released into the cytoplasm [24].

Coronavirus lifecycle proceeds with the translation of the replicase gene from their genomic RNA, where the polyproteins ppla and pplab encoded from two large ORFs $[25,26]$. Polyproteins of coronaviruses are further cleaved by a group of proteases [27, 28].

Importantly, many non-structural proteins (nsps) are assembling the replicase-transcriptase complex (RTC) needed for RNA synthesis, while specifically nsp 12 encodes the
RNA-dependent RNA polymerase (RdRp) domain, arguably the most important enzyme for the replication of the virus. This is the enzyme that will elongate new positive sense RNA molecules from the original RNA of the virion [29].

Subgenomic RNAs (sgRNAs) are abundantly produced by the virus. SgRNAs serve as mRNAs mainly for the structure of the virus. Importantly, homologous and nonhomologous recombination can happen in the virus genome at this stage [30, 31].

After replication and sgRNA synthesis, S, E, and M structural proteins are translated and transferred into the endoplasmic reticulum (ER). These proteins move to the endoplasmic reticulum-Golgi intermediate compartment (ERGIC) [32,33] and are encapsulated into membranes to form mature virions [34]. The M protein is responsible for most protein-protein interactions required for assembly of coronaviruses, while the E protein functions as a chaperone to the $\mathrm{M}$ protein [35]. Lastly, the $\mathrm{S}$ (spike) protein that is not required for assembly is transferred to virions by interacting with the $\mathrm{M}$ protein. As already stated, the trimeric $\mathrm{S}$ protein is the spike-like protein on the surface of the virus [36, 37] and acts as a class I fusion protein [24] that ensures attachment to the host receptor. Following assembly, newly made viruses transport to the cell surface and are released to the environment by exocytosis [38].

\section{Viral Conjunctivitis}

Conjunctivitis, or pink eye, is an irritation or inflammation of the conjunctiva, which covers the white part of the eyeball [39]. It can be caused by bacteria, viruses, or allergies. It can be contagious as it is spread by contact with eye secretions. Symptoms include itching, redness, and tearing of the eyes. It can also lead to discharge or crusting around the eyes [40].

It is important to stop wearing contact lenses while affected by conjunctivitis. While allergic conjunctivitis can be treated with antihistamines and bacterial conjunctivitis can be treated with antibiotic eye drops to speed up the recovery process, the only way to recover from viral conjunctivitis is to let it resolve on its own while taking care of the overall good health of the patient [41].

Adenovirus is the most common cause of viral conjunctivitis. Viruses of the Adenoviridae family consist of nonenveloped, double-stranded DNA. The most frequent infections caused by the adenovirus are eye infections, upper respiratory tract infections, and diarrhea in children [42]. Except for adenovirus derived, herpes conjunctivitis is also common in children [43]. Except for DNA viruses though, RNA viruses are often associated with conjunctivitis. Picornaviruses can cause acute hemorrhagic conjunctivitis and are highly infectious, and HIV can also cause conjunctivitis producing redness, irritation, and tearing [44]. 


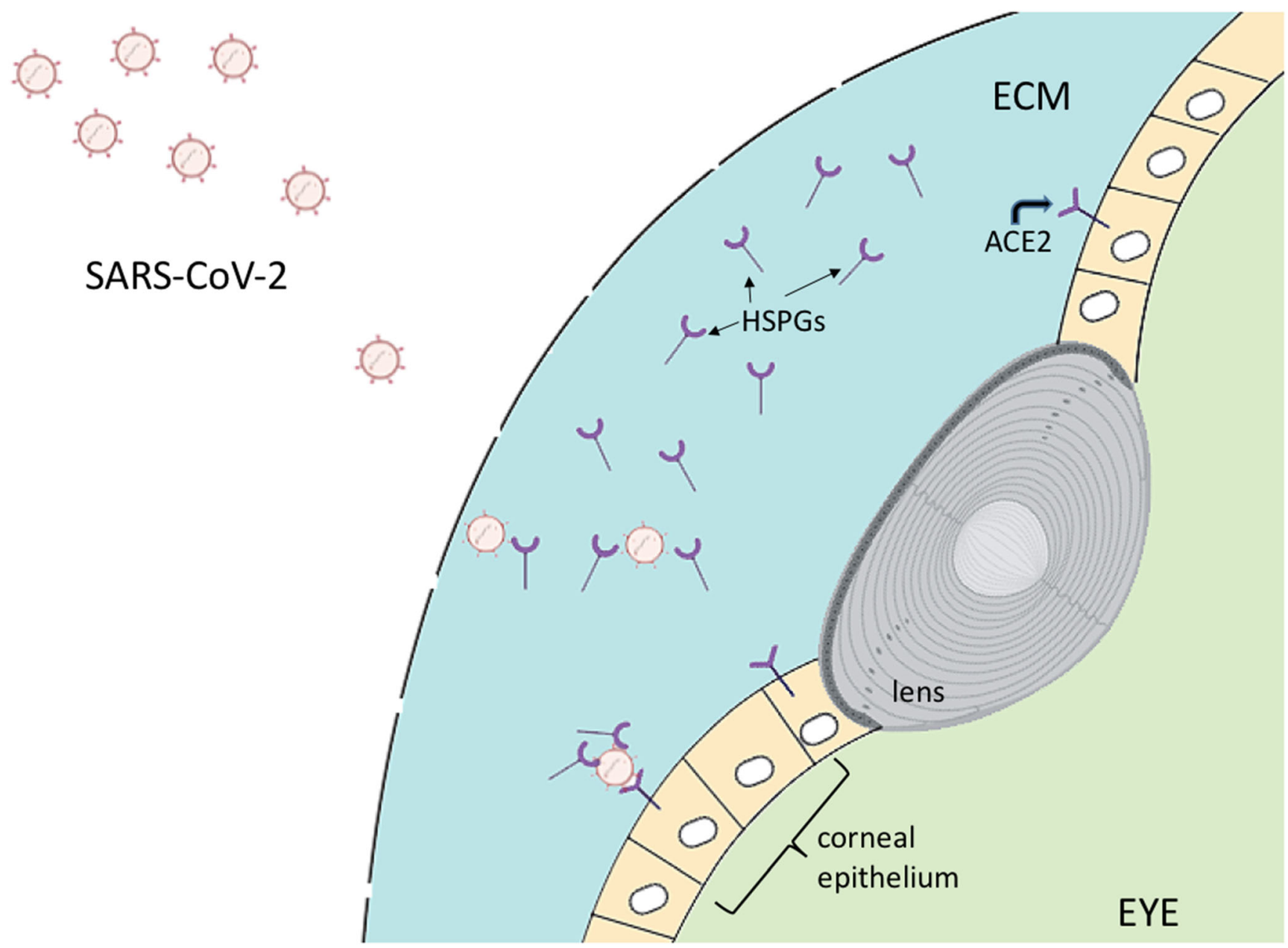

Fig. 1 SARS-CoV-2 viruses find the ACE2 receptor on corneal epithelium cells via the help of HSPG receptors in the eye's ECM

Cell infection of picornaviruses starts with its attachment to cell receptors. These receptors are subdivided into two major groups, i.e., canyon and non-canyon binders, which refers to different structures of the virus' surface $[45,46]$. Canyon receptors like ICAM-1, PV receptor, or $\alpha_{v} \beta_{3}$ and $\alpha_{v} \beta_{6}$ integrin receptors bind into the canyon of the viral surface, triggering conformational changes of the virus essential for infection, while non-canyon binders such as the LDL receptor, Pselectin glycoprotein ligand-1 (PSGL-1), and heparan sulfate proteoglycan (HSPG) receptors attach to the virus surface elsewhere except for the canyon, guiding the virus to the host cell surface and as a result signal for virus endocytosis [47-50]. The HSPGs are continuously reported as providers of an increased efficiency of viral attachment to host cells, thus allowing the binding of the virus to another receptor [51-53].

\section{Conjunctivitis as a COVID-19 Symptom}

It is not uncommon for coronaviruses to be found in tears through the years. SARS-CoV, HCoV-NL63, and SARS$\mathrm{CoV}-2$ coronaviruses have been detected active through RTPCR in tears in previous coronavirus outbreaks [54-58]. On the other hand, other studies have shown no evidence of live viruses in tears of patients infected with several different strains of coronaviruses $[59,60]$.

Given the uprising number of publications and case reports of COVID-19 patients showing conjunctivitis [61, 62] and the history of other coronaviruses that are found in tears, we have to consider the possibility of a separate, alternative viral mechanism through which the virus can enter the patient's organism through epithelial cells of the eye [63]. The growing evidence on COVID-19 and its ocular implications and manifestations, in both animals and humans, is covered by many interesting reviews, all published 5 to 6 months after the novel coronavirus' outbreak [64-68], something that reveals the need to understand the virus from different perspectiveswhich at first may have seemed secondary in priority - in order to be able to reach a treatment.

\section{Discussion}

As not much has been yet published about the SARS-CoV-2 pathogenic mechanism, from genomic and structural analyses, 
it is known that the SARS-CoV-2 has a similar receptor binding mechanism as SARS-CoV. The angiotensin-converting enzyme-2 (ACE2) receptor is so far the best candidate for the main entry mechanism of SARS-CoV-2 [69].

The ocular surface is comprised by the conjunctival and corneal epithelia which are connected to the upper respiratory system [70]. Liquid from the eye is absorbed by the conjunctiva and cornea epithelium and drained into the nasal cavity through the nasolacrimal duct to the respiratory tract through the trachea [71]. As a result, pathogens from the eye can be transported to the respiratory system.

Interestingly, the human eye has its own intraocular angiotensin system (RAS), which has been popular as a way of antiglaucoma drug development. As secondary evidence, ACE2, the main entry receptor of HCoV-NL63, SARS$\mathrm{CoV}$, and SARS-CoV-2, has been found in the aqueous humor [72] and at the conjunctival epithelial cells of the ocular surface [73]. However, ACE2 expression in human ocular surface is much lower than in other tissues [74].

Besides the immune conditions of the host, the efficiency of a virus infection depends on the infection rate of the virus and the viral receptors on the host cell membrane. As with picornavirus and other viruses, HSPG receptors are known to create a first attachment of the virus close to an epithelium that consists of cells with a low number of the ACE2 receptors. The entry of the virus inside these cells is facilitated through the ACE2 receptors, but HSPGs provide an environment of enrichment of the virus load close to the host cells through low affinity interactions [45].

While the exact mechanism still remains unclear, many investigations point to the fact that the infection of SARS$\mathrm{CoV}$ and HCoV-NL63 into human cells is mediated by more receptors other than ACE2 on host cell membrane. Among other factors, HSPGs can clearly also serve as first attachment receptors [75]. First, the virus is docked to the host cells with a first link between the $\mathrm{S}$ protein on viral surface and the heparan sulfate chains of HSPGs on the host cell membrane [76, 77]. This binding event acts as an anchor for the more stable binding of the S protein to ACE2 receptor of the host cell membrane, followed by endocytosis of the viral particles $[78,79]$. As shown in Fig. 1, this is very likely to be the mechanism of the invasion of SARS-CoV-2 in the epithelial cell of the cornea and conjunctiva as well.

By better understanding the mechanism discussed here with more clinical and experimental trials, ophthalmologists can play a major role on tracking early symptoms of COVID19 and helping in the better treatment of the disease.

Compliance with Ethical Standards There was no research involving human participants or animals for the preparation of this review.

Conflict of Interest The author declares that there are no conflicts of interest.

\section{References}

1. Lu R, Zhao X, Li J, Niu P, Yang B, Wu H, et al. Genomic characterisation and epidemiology of 2019 novel coronavirus: implications for virus origins and receptor binding. Lancet. 2020;395(10224):565-74.

2. Zhai P, et al. The epidemiology, diagnosis and treatment of COVID-19. Int J Antimicrob Agents. 2020;55:105955.

3. Elfiky AA. Ribavirin, Remdesivir, Sofosbuvir, Galidesivir, and Tenofovir against SARS-CoV-2 RNA dependent RNA polymerase (RdRp): a molecular docking study. Life Sci. 2020;253:117592.

4. Elfiky AA. Anti-HCV, nucleotide inhibitors, repurposing against COVID-19. Life Sci. 2020;248:117477.

5. Sheahan TP, Sims AC, Leist SR, Schäfer A, Won J, Brown AJ, et al. Comparative therapeutic efficacy of remdesivir and combination lopinavir, ritonavir, and interferon beta against MERS-CoV. Nat Commun. 2020;11(1):222.

6. Gordon CJ, Tchesnokov EP, Feng JY, Porter DP, Götte M. The antiviral compound remdesivir potently inhibits RNA-dependent RNA polymerase from Middle East respiratory syndrome coronavirus. J Biol Chem. 2020;295(15):4773-9.

7. Gao J, Hu S. Update on use of chloroquine/hydroxychloroquine to treat coronavirus disease 2019 (COVID-19). Biosci Trends. 2020.

8. Russell CD, Millar JE, Baillie JK. Clinical evidence does not support corticosteroid treatment for 2019-nCoV lung injury. Lancet. 2020;395(10223):473-5.

9. Mulangu S, Dodd LE, Davey RT Jr, Tshiani Mbaya O, Proschan M, Mukadi D, et al. A randomized, controlled trial of Ebola virus disease therapeutics. N Engl J Med. 2019;381(24):2293-303.

10. Mair-Jenkins J, Saavedra-Campos M, Baillie JK, Cleary P, Khaw FM, Lim WS, et al. The effectiveness of convalescent plasma and hyperimmune immunoglobulin for the treatment of severe acute respiratory infections of viral etiology: a systematic review and exploratory meta-analysis. J Infect Dis. 2015;211(1):80-90.

11. Duan K, Liu B, Li C, Zhang H, Yu T, Qu J, et al. Effectiveness of convalescent plasma therapy in severe COVID-19 patients. Proc Natl Acad Sci U S A. 2020;117(17):9490-6.

12. Chen $\mathrm{S}, \mathrm{Yu} \mathrm{X}$, Guo D. CRISPR-Cas targeting of host genes as an antiviral strategy. Viruses. 2018;10(1).

13. Knott GJ, East-Seletsky A, Cofsky JC, Holton JM, Charles E, O'Connell MR, et al. Guide-bound structures of an RNA-targeting A-cleaving CRISPR-Cas13a enzyme. Nat Struct Mol Biol. 2017;24(10):825-33.

14. Abbott TR, Dhamdhere G, Liu Y, Lin X, Goudy L, Zeng L, et al. Development of CRISPR as an antiviral strategy to combat SARSCoV-2 and influenza. Cell. 2020;181:865-876.e12.

15. Wrapp D, Wang N, Corbett KS, Goldsmith JA, Hsieh CL, Abiona O, et al. Cryo-EM structure of the $2019-\mathrm{nCoV}$ spike in the prefusion conformation. Science. 2020;367(6483):1260-3.

16. Du L, et al. The spike protein of SARS-CoV-a target for vaccine and therapeutic development. Nat Rev Microbiol. 2009;7(3):226-36.

17. Bai Y, Yao L, Wei T, Tian F, Jin DY, Chen L, et al. Presumed asymptomatic carrier transmission of COVID-19. JAMA. 2020;323:1406.

18. Rothe C, Schunk M, Sothmann P, Bretzel G, Froeschl G, Wallrauch C, et al. Transmission of 2019-nCoV infection from an asymptomatic contact in Germany. N Engl J Med. 2020;382(10):970-1.

19. Yuen KS, Ye ZW, Fung SY, Chan CP, Jin DY. SARS-CoV-2 and COVID-19: the most important research questions. Cell Biosci. 2020;10:40.

20. Zhou P, Yang XL, Wang XG, Hu B, Zhang L, Zhang W, et al. A pneumonia outbreak associated with a new coronavirus of probable bat origin. Nature. 2020;579(7798):270-3.

21. Maier HJ, Bickerton E, Britton P. Preface. Coronaviruses. Methods Mol Biol. 2015;1282:v. 
22. Keep SM, Bickerton E, Britton P. Transient dominant selection for the modification and generation of recombinant infectious bronchitis coronaviruses. Methods Mol Biol. 2015;1282:115-33.

23. Kubo H, Yamada YK, Taguchi F. Localization of neutralizing epitopes and the receptor-binding site within the amino-terminal 330 amino acids of the murine coronavirus spike protein. J Virol. 1994;68(9):5403-10.

24. Bosch BJ, Martina BEE, van der Zee R, Lepault J, Haijema BJ, Versluis $C$, et al. Severe acute respiratory syndrome coronavirus (SARS-CoV) infection inhibition using spike protein heptad repeat-derived peptides. Proc Natl Acad Sci U S A. 2004;101(22): 8455-60.

25. Baranov PV, Henderson CM, Anderson CB, Gesteland RF, Atkins JF, Howard MT. Programmed ribosomal frameshifting in decoding the SARS-CoV genome. Virology. 2005;332(2):498-510.

26. Brierley I, Digard P, Inglis SC. Characterization of an efficient coronavirus ribosomal frameshifting signal: requirement for an RNA pseudoknot. Cell. 1989;57(4):537-47.

27. Ziebuhr J, Snijder EJ, Gorbalenya AE. Virus-encoded proteinases and proteolytic processing in the Nidovirales. J Gen Virol. 2000;81(Pt 4):853-79.

28. Mielech AM, Chen Y, Mesecar AD, Baker SC. Nidovirus papainlike proteases: multifunctional enzymes with protease, deubiquitinating and deISGylating activities. Virus Res. 2014;194:184-90.

29. Snijder EJ, Bredenbeek PJ, Dobbe JC, Thiel V, Ziebuhr J, Poon LLM, et al. Unique and conserved features of genome and proteome of SARS-coronavirus, an early split-off from the coronavirus group 2 lineage. J Mol Biol. 2003;331(5):991-1004.

30. Keck JG, et al. RNA recombination of coronavirus. Adv Exp Med Biol. 1987;218:99-107.

31. Keck JG, Stohlman SA, Side LH, Makino S, Lai MMC. Multiple recombination sites at the 5'-end of murine coronavirus RNA. Virology. 1987;156(2):331-41.

32. Krijnse-Locker J, Ericsson M, Rottier PJ, Griffiths G. Characterization of the budding compartment of mouse hepatitis virus: evidence that transport from the RER to the Golgi complex requires only one vesicular transport step. J Cell Biol. 1994;124(12):55-70.

33. Tooze J, Tooze S, Warren G. Replication of coronavirus MHV-A59 in sac- cells: determination of the first site of budding of progeny virions. Eur J Cell Biol. 1984;33(2):281-93.

34. de Haan CA, Rottier PJ. Molecular interactions in the assembly of coronaviruses. Adv Virus Res. 2005;64:165-230.

35. Ye Y, Hogue BG. Role of the coronavirus $\mathrm{E}$ viroporin protein transmembrane domain in virus assembly. J Virol. 2007;81(7): 3597-607.

36. Beniac DR, Andonov A, Grudeski E, Booth TF. Architecture of the SARS coronavirus prefusion spike. Nat Struct Mol Biol. 2006;13(8):751-2.

37. Delmas B, Laude H. Assembly of coronavirus spike protein into trimers and its role in epitope expression. J Virol. 1990;64(11): 5367-75.

38. Collins AR, Knobler RL, Powell H, Buchmeier MJ. Monoclonal antibodies to murine hepatitis virus-4 (strain JHM) define the viral glycoprotein responsible for attachment and cell-cell fusion. Virology. 1982;119(2):358-71.

39. Stenson S, Newman R, Fedukowicz H. Laboratory studies in acute conjunctivitis. Arch Ophthalmol. 1982;100(8):1275-7.

40. Sen E, Celik S, Inanc M, Elgin U, Ozyurt B, Yilmazbas P. Seasonal distribution of ocular conditions treated at the emergency room: a 1year prospective study. Arq Bras Oftalmol. 2018;81(2):116-9.

41. O'Brien TP, et al. Acute conjunctivitis: truth and misconceptions. Curr Med Res Opin. 2009;25(8):1953-61.
42. Li J, Lu X, Jiang B, du Y, Yang Y, Qian H, et al. Adenovirusassociated acute conjunctivitis in Beijing, China, 2011-2013. BMC Infect Dis. 2018;18(1):135.

43. Sow AS, Kane H, Ka AM, Hanne FT, Ndiaye JMM, Diagne JP, et al. Senegalese experience with acute viral conjunctivitis. J Fr Ophtalmol. 2017;40(4):297-302.

44. Solano D, Czyz CN. Viral conjunctivitis. Treasure Island: StatPearls; 2020

45. Cifuente JO, Moratorio G. Evolutionary and structural overview of human picornavirus capsid antibody evasion. Front Cell Infect Microbiol. 2019;9:283.

46. Rossmann MG. The canyon hypothesis. Hiding the host cell receptor attachment site on a viral surface from immune surveillance. J Biol Chem. 1989;264(25):14587-90.

47. Verdaguer N, Fita I, Reithmayer M, Moser R, Blaas D. X-ray structure of a minor group human rhinovirus bound to a fragment of its cellular receptor protein. Nat Struct Mol Biol. 2004;11(5):429-34.

48. Baggen J, Hurdiss DL, Zocher G, Mistry N, Roberts RW, Slager JJ, et al. Role of enhanced receptor engagement in the evolution of a pandemic acute hemorrhagic conjunctivitis virus. Proc Natl Acad Sci U S A. 2018;115(2):397-402.

49. Bergelson JM, Cunningham JA, Droguett G, Kurt-Jones EA, Krithivas A, Hong JS, et al. Isolation of a common receptor for Coxsackie B viruses and adenoviruses 2 and 5. Science. 1997;275(5304):1320-3.

50. Escribano-Romero E, Jimenez-Clavero MA, Gomes P, GarcíaRanea JA, Ley V. Heparan sulphate mediates swine vesicular disease virus attachment to the host cell. J Gen Virol. 2004;85(Pt 3): 653-63.

51. Mettenleiter TC, Zsak L, Zuckermann F, Sugg N, Kern H, BenPorat T. Interaction of glycoprotein gIII with a cellular heparinlike substance mediates adsorption of pseudorabies virus. J Virol. 1990;64(1):278-86.

52. Asagoe T, et al. Effect of heparin on infection of cells by equine arteritis virus. J Vet Med Sci. 1997;59(8):727-8.

53. Jackson T, Ellard FM, Ghazaleh RA, Brookes SM, Blakemore WE, Corteyn $\mathrm{AH}$, et al. Efficient infection of cells in culture by type $\mathrm{O}$ foot-and-mouth disease virus requires binding to cell surface heparan sulfate. J Virol. 1996;70(8):5282-7.

54. Xia J, Tong J, Liu M, Shen Y, Guo D. Evaluation of coronavirus in tears and conjunctival secretions of patients with SARS-CoV-2 infection. J Med Virol. 2020;92:589-94.

55. Li JO, et al. Novel coronavirus disease 2019 (COVID-19): the importance of recognising possible early ocular manifestation and using protective eyewear. Br J Ophthalmol. 2020;104(3):297-8.

56. Zhang X, Chen X, Chen L, Deng C, Zou X, Liu W, et al. The evidence of SARS-CoV-2 infection on ocular surface. Ocul Surf. 2020;18:360-2.

57. Salducci M, La Torre G. COVID-19 emergency in the cruise's ship: a case report of conjunctivitis. Clin Ter. 2020;171(3):e189-91.

58. Vabret A, Mourez T, Dina J, van der Hoek L, Gouarin S, Petitjean J, et al. Human coronavirus NL63, France. Emerg Infect Dis. 2005;11(8):1225-9.

59. Wang D, et al. Clinical characteristics of 138 hospitalized patients with 2019 novel coronavirus-infected pneumonia in Wuhan, China. JAMA. 2020

60. Chan WM, Yuen KS, Fan DS, Lam DS, Chan PK, Sung JJ. Tears and conjunctival scrapings for coronavirus in patients with SARS. Br J Ophthalmol. 2004;88(7):968-9.

61. Chiotos K, et al. Multisystem inflammatory syndrome in children during the COVID-19 pandemic: a case series. J Pediatric Infect Dis Soc. 2020.

62. Chen L, Deng C, Chen X, Zhang X, Chen B, Yu H, et al. Ocular manifestations and clinical characteristics of 535 cases of COVID-19 in Wuhan, China: a cross-sectional study. Acta Ophthalmol. 2020. 
63. Seah I, Agrawal R. Can the coronavirus disease 2019 (COVID-19) affect the eyes? A review of coronaviruses and ocular implications in humans and animals. Ocul Immunol Inflamm. 2020;28(3):391-5.

64. Ying NY, et al. Coronavirus disease 2019 presenting as conjunctivitis. Korean J Fam Med. 2020.

65. Bacherini D, Biagini I, Lenzetti C, Virgili G, Rizzo S, Giansanti F. The COVID-19 pandemic from an ophthalmologist's perspective. Trends Mol Med. 2020;26(6):529-31.

66. Dockery DM, Rowe SG, Murphy MA, Krzystolik MG. The ocular manifestations and transmission of COVID-19: recommendations for prevention. J Emerg Med. 2020.

67. Amesty MA, Del Barrio JLA, Alio JL. COVID-19 disease and ophthalmology: an update. Ophthalmol Therapy. 2020.

68. Kuo IC, O'Brien TP. COVID-19 and ophthalmology: an underappreciated occupational hazard. Infect Control Hosp Epidemiol. 2020:1-2.

69. Wan Y, et al. Receptor recognition by the novel coronavirus from Wuhan: an analysis based on decade-long structural studies of SARS coronavirus. J Virol. 2020;94(7).

70. Belser JA, Rota PA, Tumpey TM. Ocular tropism of respiratory viruses. Microbiol Mol Biol Rev. 2013;77(1):144-56.

71. Tong TR, Lam BH, Ng TK, Lai ST, Tong MK, Chau TN. Conjunctiva-upper respiratory tract irrigation for early diagnosis of severe acute respiratory syndrome. J Clin Microbiol. 2003;41(11):5352.

72. Holappa M, Vapaatalo H, Vaajanen A. Many faces of reninangiotensin system - focus on eye. Open Ophthalmol J. 2017;11: $122-42$.
73. Hamming I, Timens W, Bulthuis MLC, Lely AT, Navis GJ, van Goor $\mathrm{H}$. Tissue distribution of ACE2 protein, the functional receptor for SARS coronavirus. A first step in understanding SARS pathogenesis. J Pathol. 2004;203(2):631-7.

74. Liao Y, Lescar J, Tam JP, Liu DX. Expression of SARS-coronavirus envelope protein in Escherichia coli cells alters membrane permeability. Biochem Biophys Res Commun. 2004;325(1):374-80.

75. Milewska A, et al. Entry of human coronavirus NL63 into the cell. J Virol. 2018;92(3).

76. Lang J, Yang N, Deng J, Liu K, Yang P, Zhang G, et al. Inhibition of SARS pseudovirus cell entry by lactoferrin binding to heparan sulfate proteoglycans. PLoS One. 2011;6(8):e23710.

77. Raj VS, Mou H, Smits SL, Dekkers DHW, Müller MA, Dijkman R, et al. Dipeptidyl peptidase 4 is a functional receptor for the emerging human coronavirus-EMC. Nature. 2013;495(7440):251-4.

78. Orr-Burks N, Gulley SL, Gallardo RA, Toro H, van Ginkel FW. Immunoglobulin A as an early humoral responder after mucosal avian coronavirus vaccination. Avian Dis. 2014;58(2):279-86.

79. Milewska A, Zarebski M, Nowak P, Stozek K, Potempa J, Pyrc K. Human coronavirus NL63 utilizes heparan sulfate proteoglycans for attachment to target cells. J Virol. 2014;88(22):13221-30.

Publisher's Note Springer Nature remains neutral with regard to jurisdictional claims in published maps and institutional affiliations. 